\title{
Health of Public Life in the philosophy of Hannah Arendt: the relation of the public and private realms in the centuries of modernity
}

\section{DOI: $\underline{\text { http://doi.org/10.26758/8.1.21 }}$}

\section{Gábor Kovács}

Senior Research Fellow, Institute of Philosophy, Research Centre for the Humanities, Hungarian Academy of Sciences, Budapest, Hungary

Address correspondence to: Gábor Kovács, E-mail: kovacs.gabor@btk.mta.hu

\begin{abstract}
In The Human Condition (1959), which is mentioned as her opus magnum, Arendt gives a political ontology applying a phenomenological method; she blends the chronological explanation with a conceptual analysis. The axis of thought train is the private-public distinction put in a historical framework. The feminist authors warn us, that this distinction is not a neutral analytical instrument but an abstraction deduced from the reality of the antique patriarchal society. At the same time, Arendt, in other feminist interpretations is a forerunner of feminism who, in her biography written on Rahel Varnhagen, a Jewish woman of Berlin in the first half of the $19^{\text {th }}$ century, created a role model of modern woman who dared to risk of entering the light of the public realm that had previously been dominated by males and, in her Berlin saloon, offered an alternative space where the women were peers of men. The pro-Arendt feminist interpreters assert, the Arendtian philosophy outlines the possibility for a no male-dominated, really democratic public realm.

The political philosophy of Hannah Arendt has been flavored by a history of decline. The beginning of the modernity, in this interpretation, is the moment of derailment. During the centuries of modernity, step by step, the division lines between private and public spheres disappear. Lasting institutions, warranting the public sphere, dissolve in the never-ending procession of material production: everything becomes fluid: culture and politics change into the objects of the everwidening cycles of consumption devouring whole reality and the intimacy, conquering and distorting the emptied public realm, creates proper constellation for totalitarian political practices.
\end{abstract}

Keywords: public space, private space, equality, male, female, feminism, privacy.

\section{Introduction}

The distinction between private and public spaces has been a basic tenet of political thought since the beginning of modernity. In public space, individuals strive for gaining the respect of others. Private space is a field of particular human needs that must be excluded from public space. Is this distinction tenable in our age? Our era, this is frequently said, is un-interpretable with the classical binary notions of modernity (Hardt and Negri, 2000, p.151). The requirement of a well trenched public space with its lasting institutions, from the perspective of late or post-modernity, seems to be irrelevant. Many thinkers assert that the elimination of borders and the hybridization of life spheres are the main characteristics of our age. Zygmunt Baumann has coined the term of liquid modernity by which he refers to the overall dissolution of borders, institutions and solid, lasting identities (Baumann, 2000, pp.7-8). 
At the same time, this duality is the precondition of a healthy and well-balanced economy of human existence. Public and private spaces as autonomous, distinct, well-fenced ontological terrains are, in the interpretation of Hannah Arendt, in a complementary relation: they exclude and postulate each other at the same time. Without protected private space, the depth of human existence flattens and becomes shallow. Human beings need a home, a shelter for keeping their physical and psychical health and integrity (Arendt, 1958, p.71.) At the same time, it is true as well that, without protected public space, human existence remains one-sided and truncated.

\section{Spatial essentialism and cultural criticism: the theatre as a model for public space}

The health of public life depends on the strict separation of private and public realms - it is the core of the Arendtian approach. Both terrains of human existence have to be strictly separated from each other and entrenched within the borders of their territories - this spatial essentialism gives the basic framework of the Arendtian political philosophy. Without this separation a wellfunctioning political democracy is impossible, Arendt warns us, and many thinkers, following her argumentation, trace back the crisis symptoms of contemporary democracy to the elimination of a distinct public space. This is the basic tenet of the Arendt disciple Richard Sennett who develops his own theory within an Arendtian theoretical framework.

German Existenz-philosophy, through Jaspers and Heidegger, and the experience of Nazi totalitarianism had undoubtedly deeply influenced the thought of Arendt (Canovan, 1992; YoungBruehl, 1982). Politics conceived in the Arendtian philosophy in a definitely non-Weberian meaning; it is not a striving for power but a res publica, a common business of every citizen rooted in the human plurality; human beings live in a common world constituted and maintained by human action, which cannot be accomplished without human togetherness. The phenomenological approach is one of the most important elements of her intellectual toolbox inherited from her masters. The phenomenological description of the shared human world is the main aim of the Arendtian political phenomenology. Human existence is communal existence. The human being, according to Existenz-philosophy, has been thrown into the world but he/she exists together with others in this world. Arendt describes the ontological situation of human beings from two different perspectives; a pessimistic cultural criticism and an optimistic political philosophy. Cultural criticism is part and parcel of her German heritage of the inter-war period; it is gloomy theory describing modernity as an era of decay: human history is a history of decline (Verfallsgeschichte).

Arendt borrowed motifs mainly from her master Martin Heidegger whose existential ontology seriously influenced her approach (see Zimmerman, 1990, for the Heideggerian cultural criticism). In The Human Condition, she gives a political ontology outlined by the help of phenomenological method; she blends chronological explanation with conceptual analysis. The axis of thought train is the private-public distinction embedded in a historical framework. The beginning of the modernity is a moment of derailment; the division line between private and public spheres disappears and a new hybrid realm emerges: it is the sphere of social (see Pitkin, 1998, for the detailed analysis of social). The lasting institutions, warranties of a well-functioning public sphere, dissolve in a never-ending procession of material production: everything becomes fluid and an object of the ever-widening cycles of consumption devouring whole reality. The elimination of public realm, because of the fatal constellations of the interwar period, creates proper constellation for the totalitarian political practices of the $20^{\text {th }}$ century (Arendt, 1976).

This interpretation of the history of modernity is very similar to the theory of cultural industry explained in the common book of Adorno and Horkheimer, The dialectics of modernity. 
Modernity, in the peculiar Arendtian interpretation, is an age of re-naturalization taking place at the expense of the field of human artefacts from culture to politics (Kovács, 2012).

Her opus magnum, The Human Condition (1958) is dominated by a decline-narrative while in next book The revolution (1964) she changes her perspective; here modernity is not an age of total sinfulness anymore because modern revolutions give hope for gaining authentic political experience and recovering authentic public space (Arendt, 1990). Arendt uses the Greek polis model in which public and private space are rigorously divided from each other; the former is constituted by the polis-citizens on the agora. Liberty and equality - which are artefacts and not natural innate qualities of human beings in the Arendtian interpretation - appear in the light of public space: they are embodied in human actions and human speeches. But these are male actions and male speeches - women, similarly to the servants, are prohibited from the agora. Private realm, on the contrary, is a female terrain; it is the sphere of inequality and hierarchical relations.

\section{Arendt and the feminist perspective: Rahel Varnhagen and a $19^{\text {th }}$-century attempt for the foundation of a feminine public space.}

The Arendtian private-public distinction, the feminist authors warn us, is not a neutral analytical instrument but an abstraction deduced from the reality of the antique patriarchal society based on male domination (Pitkin, 1994). The Greek polis had been established on the institutions of slavery and the household. The latter was a scene of unequal social relations between men and women. The household gave protection to the patriarchal family in which women and children were subdued to the despotic male rule. The price of political liberty enjoyed by the men on the agora, on the stage of politics, was paid by women. However, without some kind of subjugation, it is one of the basic tenets of Arendtian political philosophy, liberty cannot exist at all: you must deliberate yourself from the burden of biological necessity including of producing foodstuff, ensuring shelter and bearing children - in the antiquity these activities were the tasks of slaves and women; the price of liberty, in premodern world, was paid by other human beings. The burden of biological necessity, in modern times, can be shifted upon machines. At the same time, this burden always remains a necessary part of human life. It can be fenced within a closed territory; household, family, factory etc. but it can't be eliminated at all. Arendt's deepest conviction is that liberty needs a closed territory exempted from necessity. Human equality is not natural; it is a fragile human artefact maintained by the political community.

Feminist interpretations of Arendt are ambivalent; it is the reflection of the ambivalence of her oeuvre. Arendtian political philosophy, as a consequence of her 'Grecophily', can really be interpreted as a macho theory: the privilege of free action in the public realm, in the space of appearance, is reserved for male agents. Arendt, her feminist critics assert, perpetuates the Greek polis model and her idealized public-political actors are typical male characters: their try to prove their own excellences, similarly to the Greek heroes of the Iliad, by ostentatious acts and speeches. They try avidly to get the admiration of the outer world concealing and overcompensating their inner uncertainty and vulnerability by glittering rhetoric and spectacular deeds (Pitkin, 1994).

This interpretation of the Arendtian political ontology is one sided but it is not without cause. The Arendtian theory for action is undeniably burdened with ambivalences (d'Entreves, 1994, pp.64-100). Arendt refers to two kinds of action without making a definite distinction between them. What is the target of the feminist critique is the agonistic-expressive action; it has been associated by Arendt with Greek polis. The male actor, acting this way, presents his excellence in an egoistic manner to the detriment of his fellow humans. At the same time, communicative action, 
contrary to the expressive type, takes place in the situations of plurality when the peers are really equal and the field of action hasn't been distorted by the conditions of subordination.

But there is another side of the coin. Seyla Benhabib, one of the pro-Arendt feminist authors, interprets Arendt as a forerunner of feminism who, in her biography written on Rahel Varnhagen, the Jewish woman of Berlin in the first half of the $19^{\text {th }}$ century, created a role model of modern woman daring to risk of entering the light of the public realm that had previously been dominated by males and, in her Berlin saloon, offered an alternative space where the women were peers of men (Benhabib, 1996, pp.20-21).

Arendt, in this early book, examining the life-situation of her heroine, connects the problem of Jewish and female identities. The historical context is Prussia, more precisely Berlin at the turn of $18-19^{\text {th }}$ centuries, during the period of the French occupation and in the consequent decades. Arendt gives a parallel analysis of different Jewish life strategies among the conditions of the Prussian nation-building in a transitional period between the mixed society of the late $18^{\text {th }}$ century and the homogenized society of the $19^{\text {th }}$-century nation-state. The referential framework is a toolbox inherited from German Existenz-philosophy. The book is a Bildung-Roman, an educational novel describing the attempt of constructing an alternative public space in a Berlin saloon where a Jewish woman, playing the role of a mediator between the Prussian bourgeoisie and the Prussian aristocracy, tries to construct for herself an identity by the way of assimilation into the Christian society of the emerging modern Prussian nation-state. Rahel Varnhagen goes over the accustomed way of assimilation of the early $19^{\text {th }}$ century: she converts from Jewish religion to Christianity and gets married to a Christian man, trying, Arendt concludes, to become a paradigmatic parvenu, but, at the end of her life, she has to realize that this life-strategy requires a total and perpetual selfsurrender from her (Arendt, 1997, p.256).

The attempts of Rahel Varnhagen fail as well on the level of public realm: her saloon of Berlin proves to be a temporary phenomenon. The cause of it is an inherent paradox built in the dynamic of modernity. At the time of the emerging of $19^{\text {th }}$ century Prussian nation state Jewish political emancipation invests Jews with political rights but, at the same time, gives rise to modern political Anti-Semitism. With the decline of the idea of a mixed society inherited from the Enlightenment the Jew ceases to be the representative of an interesting, exciting specimen of the foreigner and becomes a suspicious figure in the homogenizing atmosphere of the nation-state; the inclusivist type of alien-construction rooted in the ideas of Enlightenment is replaced by a new $19^{\text {th }}$ century exclusivist-type conception and the temporary broker-role of Rahel Varnhagen as a Jewish woman loses its ground (Arendt, 1997, p.127). At the same time, the figure of Rahel Warnhagen is important, the pro-Arendt feminist interpreters assert, because this proves that the Arendtian political philosophy anticipates the possibility for a no male-dominated, really democratic public realm, so the Arendtian theory is able to give referential points for feminism as well.

\section{The age of intimacy and the end of public realm}

The end-result of the process of dissolution taking place in an accelerating way during the centuries of modernity, in the Arendtian interpretation, is the age of intimacy and the end of public realm. Arendt (1990, p.104) distinguishes three stages of this process: the 18th century is the era of high society, in the 19th century emerges the genteel society and in the 20th century takes place the mass society, a precondition of modern totalitarianisms. The motor of these transformations is the swelling of the terrain of intimacy. The members of high society constitute a thin stratum, the aristocrats, genteel society embraces a much wider segment of the population, the bourgeoisie, mass society comprehends every member of the collectivity. The irresistible expansion of the intimacy 
contributes in a great amount to the dissolution of lasting institutions. The totalitarian regimes of the 20th centuries with their amorphous structures eliminating both public and private realms emerge from this constellation.

Naked private personality without a protecting shield, Arendt warns, corrodes and, in the long run, destroys public sphere, a terrain of human interaction based on the plurality of human beings. That is why, Arendt argues, in Greek tragedy actors hid their faces beyond masks to insulate the natural man from the artificially constructed public man:

"The profound meaningfulness inherent in the many political metaphors derived from the theatre is perhaps best illustrated by the history of the Latin word persona. In its original meaning, it signified the mask ancient actors used to wear in a play. (...) The mask as such obviously had two functions: it had to hide, or rather to replace, the actor's own face and countenance, but in a way that would make it possible for the voice to sound through. (...) the word persona became a metaphor and was carried from the language of the theatre into legal terminology. The distinction between a private individual in Rome and a Roman citizen was that the latter had a persona, a legal personality, as we would say (...) Without his persona, there would be an individual without rights and duties, perhaps a 'natural man' - that is, a human being or homo in the original meaning of the word, indicating someone outside the range of the law and the body politic of the citizens, as for instance a slave but certainly a politically irrelevant being" (Arendt, 1990, pp.106-107).

This theatre-metaphoric, in the theory of Arendt-disciple Richard Sennett, plays a central role. Sennett gives an interpretation of modernity between $18^{\text {th }}$ and $20^{\text {th }}$ centuries in which he uses the referential frame of the Arendtian thought. He focuses upon the transformations of the structure of public and private realms during these centuries. The apex, according to Sennett, was the $18^{\text {th }}$ century with a flourishing public life. It was an age when the autonomy of public space and its intactness from the intrusion of private sphere were maintained by some kind of impersonality. It had been ensured by distinctive marks; dresses, gestures, behavioral patterns promoting social interactions among foreigners who came from the different segments of society. Men were considered to be actors both on the stage of theaters and on the streets of the emerging modern metropolises as Paris and London. Shared human acts in this model are distanced from the private contents of human personality; the actors of the theatre and the persons on the streets of the city wore fictive mask-like characters concealing their personal feeling and emotions; this artificial distance-making impersonality was the most important presupposition to present a common theatrical play and to conduct shared social and political action (Sennett, 1977, pp.107-122).

The $19^{\text {th }}$ century proved a turning point in the history of modernity; naked human personality intruded into the public realm. It was a prelude to the intimate society of our age and introduced a new kind of political domination in which the politician brings the people under his/her sway by the presentation of his/her private feelings and emotions; what counts it is not his/her program or the schedule of the political acts he/she wants to realize but what he/she is like. His/her electoral success hinges on whether he/she is able to present himself/herself as an authentic personality. That kind of political manipulation involves the emergence of a collective personality, using the phrase of Sennett, a destructive gemeinschaft in a dead public space. In the ages of a vigorous, flourishing public realm collective identity has been shaped by collective action while in the ages of inflated private space without public realm collective identity has been shaped by fantasies and projection. The doer has been replaced by the passive voyeur, a collective personality motivated by fear and hate: 
"Just as personality itself has become an antisocial idea, collective personality becomes group identity in society hostile to, difficult to translate into, group activity. Community has become a phenomenon of collective being rather than collective action, save in one way. The only transaction for the group to engage in is that of purification, of rejection and chastisement of those who are not "like" the others. (...) The logic of collective personality is the purge (...) Broadly stated, when people today seek to have full and open emotional relations with each other, they succeed only in wounding each other. This is the logical consequence of the destructive gemeinschaft which arose when personality made its appearance in society" (Sennett, 1977, p.223).

\section{Conclusion}

The 'destructive gemeinschaft' arises in the late $19^{\text {th }}$ century. The Dreyfus affair analyzed in a detailed way by both Arendt and Sennett is a historical prefiguration of the $20^{\text {th }}$-century constellation leading to totalitarian regimes. Albeit totalitarianism suffered defeat, Arendt warns, without the healthy balance of mutually protected private and public realms, among the conditions distorted by the dominance of privacy, destructive gemeinschaft with its xenophobe exclusivist logic appears again and again. The post-democracy of late modernity (Crouch, 2004) can easily be a hotbed of new kinds of totalitarianism.

\section{Acknowledgment}

The paper was supported by a research project of the Hungarian Scientific Research Fund, entitled Arts and Scholarship in the Service of the Nation-building in the Nineteenth-Century Hungary (OTKA K 108670).

\section{References}

1. Arendt, H., 1976. The Origins of Totalitarianism. San Diego, New York, London, Harcourt Brace \& Company.

2. Arendt, H.,1990. On Revolution: London, Penguin Books.

3. Arendt, H., 1997. Rahel Varnhagen. The Life of a Jewess. Edited by Liliane Weissberg, translated by Richard and Clara Winston. Baltimore and London: The Johns Hopkins University Press.

4. Canovan, M., 1992. Hannah Arendt. A Reinterpretation of Her Political Thought. Cambridge: Cambridge University Press.

5. Crouch, C., 2004. Post-Democracy. Cambridge, UK-Malden, USA, Polity Press.

6. d'Entreves, M.P., 1994. The Political Philosophy of Hannah Arendt. New York: Routledge.

7. Hardt, M. and Negri, A., 2000. Empire. Cambridge, Massachusetts \& London, England: Harvard University Press, 2000.

8. Kovács, G., 2012. Hannah Arendt's Interpretation of Natural and Artificial in the Political Phenomenology of the Human Condition. Limes: Regionalistics (Vilnius), 5(2), pp.93-102.

9. Pitkin, H. F. 1994 Justice: On relating Private and Public. In: L.P. Hinchman and S.K. Hinchman, eds. Hannah Arendt. Critical Essays. New York: State University of New York Press, pp.261-88.

10. Pitkin, H.F., 1998. The Attack of the Blob.Hannah Arendt's Concept of the Social. Chicago \& London: The University of Chicago Press. 
11. Zimmerman, M., 1990. Heidegger's Confrontation with Modernity. Technology, Politics, Art. Bloomington and Indianapolis: Indiana University Press.

12. Zygmunt, B., 2000. Liquid modernity. Cambridge: Polity Press.

13. Young-Bruehl, E., 1982. Hannah Arendt. For Love of the World. New Haven and London: Yale University Press. 